\title{
JoECCE
}

Journal of Early Childhood and Character Education

\section{Peningkatan Nilai Agama dan Moral Anak Usia Dini Melalui Kegiatan Latihan Manasik Haji}

\author{
Sri Rahayu Ningsih \\ syahidaarrizqi@gmail.com \\ Hidayatu Munawaroh \\ idamuajah@gmail.com
}

\section{Universitas Sains Al-Qur'an Jawa Tengah Wonosobo}

\section{ABSTRACT}

This article aims to; 1) to find out the development of religious and moral values of children in Aisyiyah 4 Reco Kindergarten before the Hajj/Umrah pilgrimage training activities are carried out, 2) to find out how much the development of religious and moral values for early childhood in Aisyiyah 4 Reco Kindergarten is after the training activities are carried out Hajj/Umrah rituals, 3) to find out the obstacles and obstacles encountered during the implementation of the Hajj/Umrah ritual training activities at Aisyiyah 4 Reco Kindergarten. This research uses descriptive qualitative method. Collecting data using participant observation techniques, in-depth interviews and documentation. The subjects of the research are parties in TK Aisyiyah 4 Reco, including: teachers, students, and guardians of TK Aisyiyah 4 Reco. This study uses naturalistic research steps, so that data analysis is carried out directly in the field by collecting data. After carrying out the Hajj/Umrah ritual training activities, children who have MB development achievements (Start to Develop) increase to BSH (Developing As Expected), which is 5\% to 27\% Children who are BSH (Developing As Expected) increase to BSB (Developing Very Well, i.e. 13\% to 73\%. Thus, it can be concluded that Hajj/Umrah ritual training activities can improve the development of religious and moral values of early childhood in Kindergarten Aisyiyah 4 Reco.

Keywords : Improving religious and moral values of early childhood, Hajj/Umrah rituals training activities. 


\section{ABSTRAK}

Artikel ini bertujuan untuk ; 1) untuk mengetahui perkembangan nilai agama dan moral anak-anak di TK Aisyiyah 4 Reco sebelum dilaksanakan kegiatan latihan manaik haji/umrah, 2) untuk mengetahui seberapa besar peningkatan perkembangan nilai agama dan moral anak usia dini di TK Aisyiyah 4 Reco setelah dilaksanakan kegiatan latihan manasik haji/umrah, 3) untuk mengetahui hambatan dan kendala yang ditemui saat pelaksanaan keguatan latihan manasik haji/umrah di TK Aisyiyah 4 Reco. Penelitian ini mengunakan metode kualitatif deskriptif. Pengumpulan data menggunakan teknik observasi partisipan, wawancara mendalam dan dokumentasi. Subyek penelitiannya adalah pihak-pihak yang ada di TK Aisyiyah 4 Reco, diantaranya adalah: guru, siswa, dan wali murid TK Aisyiyah 4 Reco. Pada penelitian ini menggunakan langkah-langkah penelitian naturalistik, sehingga analisis data dilakukan langsung di lapanagan dengan pengumpulan data. Setelah melaksanakan kegiatan latihan manasik haji/umrah, anak yang mempunyai capaian perkembangan MB (Mulai Berkembang) meningkat menjadi BSH (Berkembang Sesuai Harapan), yaitu 5\% menjadi 27\% Anak yang BSH (Berkembang Sesuai Harapan) meningkat menjadi BSB (Berkembang Sangat Baik, yaitu 13\% menjadi 73\%. Dengan demikian dapat disimpulkan bahwa kegiatan latihan manasik haji/umrah dapat meningkatkan perkembangan nilai agama dan moral anak usia dini di TK Aisyiyah 4 Reco.

Kata kunci : Peningkatan nilai agama dan moral anak usia dini, kegiatan latihan manasik haji/umrah. 


\section{PENDAHULUAN}

Usia dini merupakan masa keemasan (golden age) yang menjadi masa paling penting kehidupan manusia. Pada masa anak usia dini juga menjadi masa yang paling kritis dalam perkembangan. Oleh karena itu, anak usia dini memerlukan perhatian yang lebih dalam hal pengasuhan, pendidikan serta pemenuhan kebutuhan nutrisinya maupun kasih sayang, khususnya nilai agama dan moral yang menjadi pondasi bagi kehidupan manusia, agar anak bisa berkembang secara baik dan optimal, namun masih ada beberapa orang tua yang kurang memperhatikan pengasuhan terhadap anak-anaknya.

Pendidikan anak usia dini mempunyai peranan penting dalam mewujudkan cita-cita atau tujuan pendidikan bangsa Indonesia sesuai Undang-Undang Nomor 20 tahun 2003 tentang system pendidikan nasional pasal 3, (Departemen Pendidikan Nasional Republik Indonesia, 2003) yang tujuannya adalah: "Mengembangkan potensi peserta didik agar menjadi manusia yang beriman dan bertaqwa kepada Tuhan Yang Maha Esa, berakhlak mulia, sehat, berilmu, cakap, kreatif, mandiri, dan menjadi warga Negara yang demokratis serta bertanggungjawab".

Salah satu sikap dasar yang harus dimiliki oleh seorang anak adalah nilai agama dan moral. Dalam berperilaku, mampu mencerminkan sikap sebagai hamba Tuhan yang bertaqwa, baik terhadap agama, kehidupan berkeluarga, bermasyarakat, berbangsa, dan bernegara. Namun masih banyak anak-anak yang kurang memiliki sikap agama dan moral yang baik dikarenakan kesibukan orang tuanya.

Dengan Pendidikan anak diharapkan memiliki fondasi yang cukup dan kokoh yaitu didasari dengan nilai agama dan moral yang baik akan membentuk fondasi yang kuat untuk membentuk karakter anak.

Pembentukan nilai agama dan moral yang baik (Novi, 2015) untuk anak usia dini tidak bisa hanya dilakukan melalui pembelajaran dan teori saja, namun perlu adanya praktik langsung yang dilakukan oleh lembaga pendidikan anak usia dini yang bersangkutan, pihak guru, maupun pihak sekolah yang lain.

Lembaga pendidikan anak usia dini, nilai-nilai agama dan moral ditanamkan dengan cara, antara lain melalui keteladanan dari guru maupun orang tua. Pembelajaran akan berempati dan lebih 
bermakna jika guru mampu mengahadirkan suasana yang berbeda dan nyata dalam bentuk kegatan sehari-hari baik di rumah maupun di rumah.

Di samping tugas seorang guru, mengembangkan nilai agama dan moral anak usia dini juga menjadi tanggung jawab orang tua. Guru dan orang tua harus bisa bekerjasama dengan baik dalam mendidik dan mengembangkan aspek-aspek perkembangan seorang anak, agar tercapai perkembangan yang optimal.

Masih kurangnya kreatifitas seorang guru dalam upaya peningkatan perkembangan nilai agama dan moral anak usia dini di lembaganya juga menjadi latar belakang penulis untuk melakukan penelitian ini.

Penelitian ini dilaksanakan di TK Aisyiah 4 Reco kelompok B desa Reco Kecamatan Kertek Kabupaten Wonosobo, Jawa Tengah.

Dari latar belakang di atas, maka dapat diambil rumusan masalah dari penelitian ini, yang antara lain adalah sebagai berikut:

1. Bagaimana perkembangan nilai agama dan moral anak-anak di TK Aisyiyah 4 Reco sebelum dilaksanakan kegiatan latihan manasik haji/umrah?

2. Bagaimana peningkatan perkembangan nilai agama dan moral anak-anak di TK Aisyiyah 4 Reco setelah dilaksanakan kegiatan latihan manasik haji/umrah?

3. Apakah ada hambatan dan kendala yang ditemui saat pelaksanaan kegiatan latihan manasik haji/umrah?

Dari rumusan masalah yang ada, maka tujuan penelitian ini adalah:

1. Untuk mengetahui perkembangan nilai agama dan moral anak-anak di TK Aisyiyah 4 Reco sebelum dilaksanakan kegiatan latihan manasik haji/umrah.

2. Untuk mengetahui peningkatan perkembangan nilai agama dan moral anak-anak di TK Aisyiyah 4 Reco setelah dilaksanakan kegiatan latihan manasik haji/umrah.

3. Untuk mengetahui hambatan dan kendala yang ditemui saat pelaksanaan kegiatan latihan manasik haji/umrah. 


\section{KAJIAN TEORI}

\section{Nilai Agama dan Moral}

Menurut Suseno (Ananda, 2017) , Nilai agama dan moral dapat dilihat dari sikap baik atau buruknya perilaku yang dimiliki seseorang dalam masyarakat sebagai warga negara. Sedangkan Pendidikan moral atau nilai moral merupakan cara seseorang untuk belajar mengikuti aturan aturan manusia yang ada dalam suatu masyarakat.

Selanjutnya, Desmita mengungkapkan bahwa perkembangan moral adalah perkembangan yang berkaitan dengan aturan dan konvensi mengenai apa yang seharusnya dilakukan oleh individu dalam interaksinya dengan orang lain.

Menurut Fiahliha (desak made kusuma wardani dan mahkamah brantasari, 2019), bahwa pendidikan nilai-nilai moral dan keagamaan pada program Pendidikan Anak Usia Dini (PAUD) merupakan pondasi yang kokoh dan sangat penting keberadaannya, dan jika itu telah tertanam pada anak sejak usia dini, hal tersebut merupakan awal yang baik bagi pendidikan anak bangsa untuk menjalani pendidikan selanjutnya. STPPA dapat dijadikan rujukan untuk mengetahui tingkat pencapaian perkembangan AUD (Nurjanah, 2018).

Pendidikan Pendidikan moral dan agama yang dilaksanakan di lingkungan sekolah yang diajarkan oleh guru memang mempunyai dampak yang cukup baik bagi seorang siswa namun pendidikan keluarga adalah pendidikan yang lebih penting seseorang akan lebih terbentuk jika dididik dengan keluarga yang baik karna keluarga merupakan madrasah pertama bagi anak. Pendidikan moral dan agama yang diberikan guru di lingkungan sekolah dan orang tua di rumah berfungsi mengembangkan potensi dasar anak agar berhati baik, berpikiran baik,, dan berperilaku baik. Pada prinsipnya strategi yang baik adalah keseimbangan antara Pendidikan moral yang diberikan di rumah serta di sekolah hal ini akan membentuk perilaku anak yang sehat dan baik. (Syamsudin, 2012).

Pendidikan agama meliputi dua dimensi hidup, yaitu penanaman rasa taqwa terhadap Allah SWT dan pengembangan rasa kemanusiaan kepada sesama. Penanaman rasa taqwa kepada Allah sebagai dimensi hidup dimulai dari 
pelaksanaan kewajiban-kewajiban formal agama yang berupa ibadah-ibadah wajib dan sunah. Guru dapat mengevaluasi ketercapaian indikator-indikator teoretik nilai-nilai agama dan moral anak usia dini yang diekpresikan anak dalam perilaku selama proses pembelajaran (Syamsudin, 2012).

Secara garis besar ruang lingkup perkembangan nilai agama dan moral anak usia dini mencakup: 1) aqidah, mengajarkan keesaan Allah, 2) Syari"ah, berhubungan dengan amal lahir dalam rangka mentaati semua peraturan dan hokum Allah, 3) Akhlak, suatu amalan yang bersifat pelengkap penyepurna bagi aqidah dan akhlak, 4) kemudian dilengkapi dengan dasar huku, islam, yaitu Al-Qur'an dan hadist serta ditambah lagi dengan sejarah islam.

Ada beberapa faktor yang mempengaruhi perkembangan nilai agama dan moral anak usia dini, yaitu: 1) faktor pembawaan (internal) dan 2) faktor lingkungan (eksternal).

Pendidikan nilai agama dan moral bagi anak usia dini erat kaitannya dengan perilaku anak. Di usia 0-6 tahun adalah usia emas yang merupakan fundamental penanaman nilai-nilai agama dan moral yang baik pada anak usia dini. Tahapantahapan perkembangan moral anak dapat dilihat dari tinjauan teoritis dan menurut berbagai disiplin ilmu yang terkait di dalamnya. Pada saat lahir, tidak ada anak manusia yang memiliki hati nurani atau skala tinggi. Sehungga setia anak yang baru lahir dapat dianggap amoral atau nonmoral. Ungkapan tersebut memberi arti bahwa kemuliaan manusia dibandingkan makhluk lainnya terletak pada keagungan manusia yang menjunjung tinggi moralitas dalam kehidupannya. Media yang dapat digunakan dalam mengajarkan nilai moral diantaranya yaitu melalui media film (Nurwita, 2019).

Lebih lanjut, Fawza Memberikan penjelasan mengenai pentingnya Pendidikan khususnya Pendidikan moral bagi pribadi anak, pada prinsipnya menjelaskan bahwa pokok pertama yang terpenting dalam pendidikan moral adalah menjadi pribadi yang mempunyai moral dalam arti seorang anak dapat belajar apa yang diharapkan kelompoknya. Harapan tersebut terperinci bagi seluruh anggota kelompok dalam bentuk hukum, kebiasaan, dan peraturan. Inilah bukti 
bahwa untuk membentuk manusia yang bermoral, diperlukan perangkat yang komprehensif dan memerlukan proses pembinaan yang panjang.

Tujuan pendidikan agama dan moral (Mulinah Khairon, 2017) diantaranya adalah merupakan salah satu upaya yang dilaksanakan untuk memberikan kesadaran tentang moral pada anak sejak dini.

Selanjutnya, tujuan pendidikan moral menurut Hasbuloh (Hasbuloh, 2016) adalah upaya untuk membantu pertumbuhan dan perkembangan jasmani dan rohani. Sedangkan tujuan moral agama atau karakter anak usia dini mnurut Vera Sardila adalah rangsangan atau stimulus untuk mengoptimalkan perkembangan anak terutama dalam tahap embentkan perilaku anak.

Dari beberapa tujuan pendidikan agama dan moral di atas, maka dapat disimulkan bahwa tujuan pendidikan agama dan moral anak usia dini adalah upaya yang dilakukan untuk menstimulus dan meningkatkan perkembangan nilai agama dan moral anak usia dini dengan harapan agar anak mampu memiliki kepribadian yang baik dalam menjalani kehidupan di masa depan dengan menjadikan landasan agama dan moral sebagai dasar kehidupannya. Guru memiliki peran guru PAUD dalam meletakkan dasar moral dan keagamaan bagi seorang anak, karena AUD cenderung menuruti perintah gurunya (Ananda, 2017).

\section{Anak Usia Dini}

Hakikat anak usia dini, khususnya anak TK diantaranya menurut Bredecam dan Copple, Brener serta Kellough yang dikutip Masitoh dalam Eliyyil Akbar (Eliyyil Akbar, 2020) sebagai berikut: anak bersifat unik, mengekspresikan perilakunya secara relative spontan, anak brsifat aktif, egosentris, meiliki rasa ingin tahu yang kuat dan antusias terhadap banyak hal, bersifat eksploratif dan berjiwa petualang, umumnya kaya akan fantasi, masih mudah frustasi, masih kurang perkembangan dalam bertindak, memiliki daya perhatian yang pendek, masa anak merupakan masa belajar yang paling potensial, semakin menunjukkan minta terhadap teman. "Islam telah mengajarkan nilai- nilai positif yang bermanfaat dalam kehidupan bermasyarakat (Inawati, 2017). 
Anak usia dini sejak lahir telah dibekali potensi yang besar oleh Allah swt untuk dikembangkan, prkembangan potensi dan fitrah tersebut ditentukan oleh pendidikan kedua orangtua dan lingkungannya. (Setiawati, 2006) Anak harus mendapat pendidikan yang baik agar dapat mengembangkan potensinya dan bermanfaat bagi lingkungan sekitar. Hal lainnya anak akan dapat mengembangkan kemampuannya dalam kehidupannya dimasa depa. Sehingga Penanaman nilai-nilai moral dan agama pada anak usia dini sangat penting sebagai pengalaman yang baik yang sudah didapatkan ketika mereka pada saat pra sekolah (Safitri, N., Kuswanto, C. W., \& Alamsyah, 2019).

\section{Manasik haji/Umrah}

Manasik haji/umrah dalam kamu besar bahasa Indonesiaa, berarti hal-hal yang berhubungan degan ibadah haji seperti ihram, thowaf, sa'i, wukuf. Sedangkan menurut Peter Saalim dan Yenni Salim, adalah penjelasan dalam bentuk tuntunan atau petunjuk kepada calon jama'ah haji tentang tata cara perjalanan dan pelaksanaan ibadah haji dengan maksud agar calon jama'ah haji dapat melaksanakan seluruh kegiatan ibadah haji secara mandiri dan memperoleh haji mambrur.

Tahapan-tahapan manasik haji (Kholillurohman, 2017) adalah: 1) mandi sunnah, ihram, 2) memakai pakaian ihram, 3) memakai wewagian di bdan, 4) merapikan rambut/kuku, 5) shalat sunnah ihram, 6) niat memakai pakaian ihram, 7) niat haji dan ihramnya di Miqat, 8) wukuf di Arafah, 9) Mabit di Muzdalifah, 10) Mencari kerikil, 11) melempar jumrah Aqobah, 12) Mabit 13 Dzullhijah, 13) Melempar Jumrah Ulla, 14) Thawaf Ifadah, 15) Sa'i.

\section{Tujuan Kegiatan Latihan Manasik Haji/Umrah untuk Anak Usia Dini}

Tujuan kegiatan latihan manasik haji/umrah ini adalah untuk menanamkan sikap religious terhadap anak usia dini, seekaligus mengenalkan rukun islam yang ke lima, yakni menjalankan ibadah haji. Selai itu, anak-anak juga belajar bagaimana cara thawaf, wukuf, sa'i, dan melempar jumrah dan prosesi ibadah haji lainnya. 


\section{METODE PENELITIAN}

Artikel ini menggunakan jenis penelitian kualitatif, penelitian kualitatif adalah bentuk penelitian yang temuan temuannya berbentuk Descriptive dengan mengungkapkan data dan ide ide secara terperinci dan dikaji secara mendalam. Menurut Eko Sugiarto (Sugiarto, 2015), penelitian kulaitatif adalah jenis penelitian yang temuan-temuannya tidak diperoleh melalui prosedur statistik atau bentuk hitungan lainnya, dan bertujuan mengungkapkan gejala secara holistickontekstual melalui pengumpulan data dari latar alami dengan memanfaatkan diri peneliti sebagai intrumen kunci. Penelitian kulaitatif berjenis deskriptis dan cenderung mengungkapkan analisis dengan pendekatan induktif. Pendekatan kualitatif (Rukin, 2019) menekankan pada pendekatan makna, penalaran, definisi suatu situasi tertentu (dalam konteks tertentu), serta lebih banyak meneliti hal-hal yang berhubungan dengan kehidupan.

Dalam melakukan penelitian ini (Wayan Suwendra, 2018), penulis menggunakan pendekatan kualitatif yang bersifat deskriptif. Datanya berupa kata-kata, gambar-gambar, dan bukan angka-angka. Jenis penelitian kulaitatif deskriptif pada penelitian ini, digunakan peneliti dengan maksud untuk memperoleh informasi mengenai upaya peningkatan nilai agama dan moral anak usia dini melalui kegiatan latihan mansik haji/umrah secara mendalam dan komprehensif. Selain itu, melalui pendekatan kualitatif, diharapkan dapat diketahui situasi dan permasalahan yang dihadapi dalam kegiatan ini.

Dalam hal ini, sebagai variable bebas (Variabel Independen) ialah "kegiatan latihan manasik haji/umrah siswa TK Aisyiyah 4 Reco", atau bisa disebut dengan variabel stimulus. Sedangkan sebagai variable terikat atau Variabel Dependent adalah "Peningkatan Nilai Agama dan Moral Anak Usia Dini di TK Aisyiyah 4 Reco Kelompok B". Variabel terikat diartikan sebagai variable yang dipengaruhi atau menjadi akibat karena adanya variable terikat.

Adapun indikator pencapaian perkembangan Nilai-nilai Agama dan Moral untuk anak kelompok B (5-6 tahun) pada penelitian ini adalah (Maria Ulfah, 2018) : Mengenal agama yang dianut, mengerjakan ibadah, berperilaku jujur, penolong, sopan, hormat, sportif, menjaga kebersihan diri dan lingkungan, mengetahui hari besar agama, dan menghormati (toleransi) agama orang lain. 
Sumber data dari penelitian ini terdiri dari beberapa unsur yaitu: kepala sekolah, Guru Kelompok B1, wali murid, siswa TK Aisyiyah 4 Reco Kelompok B1, yang berjumlah 22 anak, sebagai sasaran pengamatan peneliti yang di jadikan sebagai acuan penulisan skripsi ini.

\section{HASIL DAN PEMBAHASAN}

\section{Perkembangan Nilai Agama dan Moral Anak di TK Aisyiyah 4 Reco Sebelum Dilaksanakan Kegiatan Latihan Manasik Haji/Umrah.}

Berdasarkan hasil penelitian lapangan, peneliti menemukan bahwa perkembangan nilai agama dan moral anak di TK Aisyiyah 4 Reco cukup baik. Nilai-nilai yang dikembangkan pada anak cukup banyak, seperti hafalan do'a sehari-hari, hafalan surat pendek, praktik sholat, praktik wudlu, kemandirian, kejujuran, sopan santun, dan dijelaskan mengenai hal yang baik dan buruk.

Dari data diperoleh, dapat diketahui bahwa perkembangan nilai agama dan moral anak di TK Aisyiyah 4 Reco sebelum dilaksanakan kegiatan latihan manasik haji/umrah rata-rata sudah baik, yang Mulai Berkembang (MB) ada 5\%, Berkembang Sesuai Harapan (BSH) ada 82\%, dan yang Berkembang Sangat Baik (BSB) adalah $13 \%$.

Metode yang digunakan untuk meningkatkan aspek perkembangan nilai agama dan moral pada anak masih tergolong umum. Selain itu, di TK aisyiyah Reco juga menggunakan etode KIBAR sebagai metode yang digunakan untuk mengajarkan anak baca Al-Qur'an. Metode KIBAR merupakan metode unggulan yang ada di TK tersebut sebagai upaya untuk meningkatkan nilai agama dan moral anak-anak didiknya.

Dalam hal ini, guru bekerjasama dengan orang tua dalam menerapkan pembiasaan yang baik pada anak, terutama menjelaskan tentang mana perbuatan yang baik dan yang buruk. Seperti diungakpakan oleh Ibu Riah, bahwa untuk meningkatkan nilai agama dan moral pada anak tidak bisa hanya dilakukan oleh guru saja di sekolah, namun kerjasama dengan orang tua sangat dibutuhkan. Karena anak-anak lebih banyak waktu di rumah daripada di sekolah. Segala perilaku orang tua maupun keluarga di rumah akan sangat berpengaruh pada perilaku anak. Karena anak masih dalam tahap meniru. 
Pada saat observasi peneliti dapat menyimpulkan bahwa tahap perkembangan nilai agama dan moral pada anak di TK Aisyiyah 4 Reco sedang berada pada tahap prakonvensional. Pada anak usia dini, perkebangan moral anak termasuk dalam tahap perkembangan moral prakonvensional. Tahap ini terjadi pada anak usia 4 hingga 9 tahun. Karakteristik khas pada tahap ini adalah tingkah laku anak tunduk pada peraturan dari luar.

2. Peningkatan Perkembangan Nilai Agama dan Moral Anak di TK Aisyiyah 4 Reco Setelah Dilaksanakan Kegiatan Latihan Manasik Haji/Umrah di TK Aisyiyah 4 Reco.

Berdasarkan penelitian yang dilakukan penulis, peningkatan perkembangan nilai agama dan moral anak-anak di TK Aisyiyah 4 Reco setelah dilaksanakan kegiatan latihan mansik haji/umrah berkembang lebih baik. Setelah melaksankan kegiatan latihan manasik haji/umrah, anak yang mempunyai capaian perkembangan Mulai Berkembang (MB) menjadi Berkembang Sesuai Harapan (BSH), dan yang Berkembang Sesuai Harapan menjadi Berkembang Sangat Baik (BSB), yaitu Berkembang Sesuai Harapan (BSH) adalah 27\% dan Berkembang Sangat Baik (BSB) 73\%.

Kegiatan ini dipandang sebagai metode yang menyenangkan dan berbeda dari yang lain. Melalui kegiatan latihan manasik haji ini, anak-anak jadi mengenal ibadah haji, sebagai salah satu kewajiban umat islam sesuai rukun islam yang ke lima. Selain itu, melalui kegiatan latihan manasik haji/umrah untuk anak-anak ini, lebih mengajarkan anak tentang kegiatan keagamaan seperti praktik wudlu, sholat, do'a-do'a sehari-hari hingga bacaan-bacaan sholawat, kalimat thoyibah dan bacaan talbiyah pada kegiatan latihan manasik haji lebih mengena pada anak dalam meningkatkan nilai keagamaan pada anak.

Pelaksanaan kegiatan latihan manasik haji/umrah untuk anak usia dini dikemas melalui kegiatan yang menyenangkan dan tidak monoton sehingga anak tidak mudah bosan. Kegiatan latihan manasik haji/umrah untuk anak usia dini dilakukan dalam kegiatan yang menyenangkan,seperti menyisipkan do'a-do'anya dalam kegiatan hafalan dan kegiatan pembiasaan berupa kegiatan rutin, spontan, serta keteladanan yang diberikan oleh guru, karyawan, dan anggota warga sekolah lainnya.

Kegiatan parenting pada orangtuapun akan sangat membantu mereka dalam memahami peningkatan nilai agama dan 
moral pada anak melalui kegiatan latihan manasik haji/umrah yang benar dan yang salah, baik di sekolah maupun di rumah dan juga menambah ilmu pengetahuan orang tua tentang pentingnya perkembangan nilai agama dan moral yang baik pada anak melalui kegiatan latihan mansik haji/umrah ini. kegiatan tersebut sangat bermanfaat bagi anak, orang tua maupun guru. Anak-anak jadi mengenal ibadah haji dan melaksanakan ibadah haji secara langsung, walaupun hanya kegiatan latihan saja. Anak tahu tentang pakaian ihram dan belajar cara memakainya.

Pelaksanaan kegiatan latihan manasik haji/umrah untuk anak-anak dipandang menguntungkan berbagai pihak. Guru sebagai wakil dari orang tua saat di sekolah, merasa bangga terhadap anak didiknya yang dapat menyerap pengetahuan yang diberikannya, baik melalui teori maupun praktek. Demikian juga orang tua, saat melihat anaknya belajar mandiri ada rasa bangga dalam dirinya. Apalagi bagi anak yang sudah mandiri dan mampu melakukan kegiatan latihan manasik haji/umrah,akan menambah rasa percaya dirinya.

\section{Hambatan dan Kendala yang Ditemukan Saat Melaksanakan Latihan Manasik Haji/Umrah Pada Anak-anak di TK Aisyiyah 4 Reco.}

Yang menjadi faktor pendukung daripada peningkatan nilai agama dan moral anak usia dini melalui kegiatan latihan manasik haji/umrah di TK Aisyiyah 4 Reco antara lain faktor dukungan orang tua, guru dan pengurus komite, juga faktor lingkungan.

Faktor dukungan orang tua, guru dan pengurus komite merupakan faktor yang memegang peran penting dalam menentukan tercapainya keberhasilan dalam peningkatan nilai agama dan moral anak usia dini melalui kegiatan latihan manasik haji/umrah di TK Aisyiyah 4 Reco.

Selain itu, faktor pendukung yang lain adalah orang tua murid yang mudah diajak kerjasama dalam perencanaan kegiatan, seperti pengadaan seragam dan biaya akomodasi yang lain yang terkait dengan pelaksanaan kegiatan latihan manasik hai/umrah ini.

Dukungan dari pihak sekolah yakni kepala sekolah dan guru, maupun peran serta orang tua dan keluarga merupakan faktor pendukung yang sangat penting. Kepala sekolah dapat menyediakan fasilitas-fasilitas pendukung baik berupa fasilitas fisik seperti miniature Ka'bah, penyediaan seragam namasik/pakaian ihram 
untuk anak serta melalui berbagai pelatihan dan pemahaman tentang ibadah haji/umrah yang diselenggarakan sekolah. Di samping itu, kesabaran dan ketelatenan guru dalam mendampingi anak didiknya menjadikan kegiatan tersebut berjalan dengan baik dan benar.

Selain faktor pendukung, peneliti juga menemukan faktor yang menjadi hambatan dan kendala yang itemui pada saat pelaksanaan kegiatan latihan mansik haji/umrah di TK Aisyiyah 4 Reco.

Salah satu faktor hambatannya adalah pengetahuan baik dari pihak guru maupun wali murid tentang manasik haji usia orang tua juga mempengaruhi daya tangkap dan pola pikir. Semakin tua daya tangkap dan pola pikirnya semakin lemah, sehingga pengetahuan tentang manasik haji kurang berkembang. Selain itu, menurutnya faktor tingkat pendidikan dan pengalaman juga berpengaruh terhadap sukses tidaknya peningkatan nilai agama dan moral anak usia dini melalui kegiatan latihan manasik haji/umrah di TK Aisyiyah 4 Reco.

Pendidikan memiliki peran yang cukup penting, guru atau orang tua yang berpendidikan memadai akan mudah menerima informasi sehingga semakin banyak pula pengetahuan yang dimiliki orang tua. Sebaliknya dengan pendidikan yang kurang maka akan mengalami kesulitan dalam menerima pengetahuan tentang peningkatan nilai agama dan moral pada anak melalui kegiatan latihan manasik haji/umrah di TK Aisyiyah 4 Reco. Sementara pengalaman seseorang tentang manasik haji akan diperoleh dari pengalaman sendiri maupun orang lain. Dengan demikian, seorang guru atau orang tua yang belum pernah mendapatkan pengalaman melaksanakan ibadah haji akan penjadi penghambat dalam penigkatan nilai agama dan moral anak usia dini melalui kegiatan latihan mansik haji/umrah. Di TK Aisyiyah 4 Reco.

Faktor yang menjadi hambatan dalam kegiatan tersebut yang berasal dari diri anak adalah anak yang masih suka bermain-main sendiri ketika melaksanakan latihan manasik haji/umrah. Saat pelaksanaan kegiatan, anak-anak merasa sangat antusias sehingga anak menjadi sulit diatur, seperti lari-lari di lapangan tempat kegiatan, karena ini dilaksanakan di lapangan terbuka atau tempat wisata, konsentrasi anak mudah terganggu, karena di tempat kegiatan latihan manasik haji/umrah banyak arena bermain yang lain, anak berebut batu saat akan melaksanakan lempar jumroh, 
anak sulit memakai pakaian ihram, terutama bagi anak laki-laki, karena tidak nyaman, maka ada yang rewel, anak yang masih pemalu atau ingin selalu dengan ibu, jadi tidak mengikuti kegiatan ini bersama teman-teman yang lain, tenaga pendidik yang masih kurang sehingga pada setiap bagian ada yang tidak dijaga oleh guru. Selain itu, faktor pengalaman guru dan orang tua tentang ibadah haji, sehingga kadang masih ada yng bingung saat melaksanakan proses kegiatan latihan manasik haji/umrah.

\section{KESIMPULAN}

1. Perkembangan Nilai Agama dan Moral Anak di TK Aisyiyah 4 Reco sebelum dilaksanakan kegiatan latihan manasik haji/umrah ratarata sudah cukup baik atau Berkembang Sesuai Harapan (BSH). Nilai-nilai yang dikembangkan pada anak cukup banyak, seperti nilai keagamaan, yaitu dengan hafalan do'a-do'a sehari-hari, hafalan surat pendek, praktik sholat, kemandirian, kejujuran, sopan santun, dan dijelaskan mengenai hal yang baik dan buruk. Selain itu, di TK Aisyiyah 4 Reco juga menggunakan metode KIBAR, yaitu metode atau program unggulan yang dimiliki oleh lembaga TK Aisyiyah 4 Reco dalam meningkatkan kemamuan baca Al-Qur'an anak.

2. Peningkatan Nilai Agama dan Moral Anak Usia Dini di TK Aisyiyah 4 Reco setelah dilaksanakan kegiatan latihan manasik haji/umrah mengalami perkembangan yang lebih baik. Tingkat pencapaian perkembangan anak dari yang Mulai Berkembang (MB) menjadi Berkembang Sesuai Harapan (BSH), dan yang Berkembang Sesuai Harapan (BSH) menjadi Berkembang Sangat Baik (BSB). Kegiatan latihan manasik haji ini menjadi kegiatan yang menyenangkan karena mampu membuat anak lebih bersemangat, karena mereka belajar dengan suasana yang berbeda. Praktik langsung dan karyawisata yang membuat anak lebih antusias dalam belajar hal keagamaan, terutama ibadah haji. Melalui kegiatan latihan manasik haji/umrah, anak-anak belajar lebih menghafal do'a-do'a manasik dan do'a harian, praktik wudlu dan sholat. Selain itu, melalui rangkaian manasik haji/umrah, anak-anak dilatih untuk jujur, disiplin dan pantang menyerah. Seperti dalam kegiatan Thowaf, Sa'I, dan melempar Jumroh. 
3. Hambatan dan kendala yang ditemukan dalam pelaksanaan kegiatan latihan manasik haji/umrah di TK Aisyiyah 4 antara lain adalah dari faktor anak yang masih aktif atau lari-larian ketika di lapangan, saling berebut batu saat hendak melaksanakan lempar jumroh, ketidaknyamanan anak dalam memakai pakaian ihram, terutama bagi anak laki-laki, anak yang pemalu sehingga tidak mengikuti kegiatan latihan manasik haji bersama teman-teman yang lain. Disamping itu dari faktor guru, kurangnya tenaga pendidik, sehingga di setiap titik yang seharusnya ada penjaga, menjadi tidak dijaga. Selain itu juga dari faktor orang tua, adalah kurangnya pengetahuan dan pengalaman orang tua maupun guru tentang manasik haji. Orang tua maupun guru yang belum pernah melaksanakan ibadah haji tentunya belum mempunyai pengalaman yang nyata tentang manasik haji, sehingga diperlukan latihan dan penjelasan mengenai maksud dan tujuan diadakannya kegiatan tersebut. Sehingga Kepala Sekolah mengadakan pelatihan manasik haji terhadap guru, anak-anak, maupun walimurid sebelum pelaksanaan kegiatan latihan manasik haji/umrah dengan tujuan agar kegiatan terebut bisa berjalan dengan baik.

\section{DAFTAR PUSTAKA}

Ananda, R. (2017). implementasi nilai- nilai moral pada anak usia dini. Jurnal Pendidikan Anak Usia Dini, 01(01), 3.

Departemen Pendidikan Nasional Republik Indonesia. (2003). Undang

- undang Republik Indonesia No.20 Tahun 2003. Jakarta.

desak made kusuma wardani dan mahkamah brantasari. (2019).

Peningkatan nilai - nilai agama dan moral pada anak kelompok B.

Jurnal Pendidikan Dan Pembelajaran Anak Usia Dini, 04(02), 99.

Eliyyil Akbar. (2020). NoMetode Belajar Anak Usia Dini. Jakarta:

Kencana.

Hasbuloh. (2016). Model Pengembangan Kurikulum Paud. Jurnal Pendidikan Guru Roudhotul Athfal, 1(1), 28.

Inawati, A. (2017). Strategi pengembangan moral dan nilai agama untuk anak usia dini. Al-Athfal: Jurnal Pendidikan Anak, 3(1), 5164.

Kholillurohman. (2017). Hajinya Lansia Ditinjau Dari Perspektif Bimbingan dan Konselling Islam. Jurnal Dakwah Dan Komunikasi, 2(2), 233. 
Maria Ulfah. (2018). Buku Saku Guru Pendidikan Anak Usia Din. Sulawesi Selatan: Aksara Timur.

Mulinah Khairon. (2017). Pendidikan Moral Pada Anak Usia Dini. Jurnal Golden Age Univerditas Hamzanwadi, 1(1), 8.m.

Novi, B. (2015). Cara - cara mengasuh anak yang sering diabaikan orang tua (Yogjakarta). Flashbooks.

Nurjanah, S. (2018). Perkembangan Nilai Agama dan Moral (STTPA Tercapai). PARAMUROBI: JURNAL PENDIDIKAN AGAMA ISLAM, 1(1), 43-59.

Nurwita, S. (2019). Analisis Nilai-Nilai Agama dan Moral Anak Usia Dini dalam Tayangan Film Kartun Upin dan Ipin. Jurnal Obsesi: Jurnal Pendidikan Anak Usia Dini, 3(2), 506-517.

Rukin. (2019). Metodologi Penelitian Kualitatif. Sulawesi Selatan: Yayasan akmar cendekia Indonesia.

Safitri, N., Kuswanto, C. W., \& Alamsyah, Y. A. (2019). Metode Penanaman Nilai-Nilai Agama Dan Moral Anak Usia DiniMetode Penanaman Nilai-Nilai Agama Dan Moral Anak Usia Dini. Journal of Early Childhood Education (JECE), 1(2), 29-44.

Setiawati, F. A. (2006). Pendidikan moral dan nilai-nilai agama pada anak usia dini: Bukan sekedar rutinitas. Paradigma. 1(2).

Sugiarto, E. (2015). Menyusun Proposal Penelitian Kualitatif: Skripsi dan Tesis. Yogjakarta: Suaka Media.

Syamsudin, A. (2012). Pengembangan Nilai-Nilai Agama dan Moral pada Anak Usia Dini. Jurnal Pendidikan Anak, 1(2).

Wayan Suwendra. (2018). Metodologi Penelitian Kualitatif. Bandung: Nilacakra. 